\title{
EFFECT OF SEALED MUNICIPAL WASTE LANDFILL ON THE QUALITY OF UNDERGROUND WATER
}

\author{
Elżbieta Halina Grygorczuk-Petersons ${ }^{1}$, Józefa Wiater ${ }^{1}$
}

1 Department of Technology in Engineering and Environmental Protection, Bialystok University of Technology, Wiejska 45, 15-351 Bialystok, Poland, e-mail: petersons@wp.pl; j.wiater@pb.edu.pl

Received: 2015.11.12

Accepted: 2015.12.09

Published: 2016.01.06

\begin{abstract}
The aim of the study was to evaluate the impact of the landfill on the groundwater environment. The assessment of water status in the region of landfill sealed with a layer of clay with a thickness of $0.5 \mathrm{~m}$, was based on the own research and monitoring received from the municipal office, and conducted in 2007-2010. Waters flowing out of the landfill revealed an increase in pollution indicators such as: total organic carbon (TOC), concentrations of PAHs and heavy metals including zinc, cadmium, and chromium. It was demonstrated that the landfill sealed with a clay layer does not reduce the outflow of leachate to groundwater, but also that the purity of these waters is influenced by increased agricultural activity in the areas adjacent to the landfill.
\end{abstract}

Keywords: municipal waste landfill, seal made of clay, groundwater, quality.

\section{INTRODUCTION}

Until the mid-1980's, dumps and landfills in Poland were located in exploited sand and gravel pits. Only in rare cases were the ground bottoms sealed (naturally or artificially) by means of: the existence of a clay or silt layer, the use of thin films, e.g. for gardening purposes (PP, PVC, PE) with a thickness of $0.2-0.3 \mathrm{~mm}$, or covering the troughs with used containers after fertilizers [Jermołowicz 2013].

Only since 1997, the standard for production of geo-membranes during construction of landfills for solid wastes, has come into force [PN-B-10290].

Landfilling, even on a properly designed and operated facilities, however, poses many threats to the environment; one of the biggest includes the formation of leachate [Jurczyk, Koc-Jurczyk and Różalska 2011]. Leachate arises from the seepage of rainwater through the layer of waste. Part of the water is absorbed by the waste, while the remaining fills the spaces on different levels of a landfill in the form of so-called suspended water or creates leachate that collects at the bottom of the landfill, acting as a potential threat to groundwater [Butt, Lockley, Oduyemi 2008; Jurczyk, Koc-Jurczyk and Różalska 2011; Stępniak 2001; Szyszkowski 1998; Wiercik, SzymańskaPulikowska 2010]. Leachate is generated when the moisture content in the landfill exceeds its retention capacity [El-Fadel, Bou-Zeid, Chahine, Alayli 2002].

The load of contaminants accumulated in the landfill bed in some part - with the time - penetrates through the insulation used as protection of water and ground environment. The contaminants, which along with leachate passes through the insulation, is called "transition concentration" [Klimek, Wysokiński, Zawadzka-Kos, Osęka, Chrząszcz 2010]. Percolation of leachate into groundwater on the sealed landfill may occur due to the leakage or rupture of the seal. In addition, in the case of unsealed landfill, there is a risk of surface water pollution [Szyc 2003]. Thus, the migration of contaminants from the landfill is determined by the quality of insulation and permeability of geological forms in the ground of landfill. Only in case of heavy loams and clays, leachate does not penetrate into the ground [Klimek, Wysokiński, Zawadzka-Kos, Osęka, Chrząszcz 2010]. 
Water infiltrating into the waste on the landfill facilitates the course of many chemical reactions, as well as the dissolution and leaching of substances contained in wastes, causing pollution of water environment [Szyszkowski 1998; Stępniak 2001]. Water supplied with waste and those resulting from the decomposition of organic substances, is of minor importance [GrygorczukPetersons, Wiater 2012].

The presence of heavy metals (cadmium, zinc, lead, copper, nickel, chrome) [Leszczyński 2011] and polycyclic aromatic hydrocarbons (PAHs) [Koc-Jurczyk, Różak 2011], which are monitored, are a major threat to groundwater around landfills. The Commission of Environmental Toxicology, Polish Academy of Sciences, considered the polycyclic aromatic hydrocarbons the most dangerous environmental poisons with carcinogenic properties. They should not be a high risk, because such compounds are practically insoluble in water, but their activity increases in the presence of detergents in leachate, which increases the solubility of the PAHs.

The aim of the study was to evaluate groundwater quality (due to the concentration of heavy metals and PAHs) in the area of the municipal waste landfill sealed with a layer of clay.

\section{MATERIAL AND METHODS}

The study was conducted in a landfill for nonhazardous and inert wastes, open until 2010 and located on a land owned by the municipality in Podlasie province. On the landfill operated in 1990-2010, mainly household wastes from rural areas, which contained ashes and slags from home furnaces, were stored. The facility is located on a typical agricultural area around farmlands ${ }^{1}$. The proposed sub-and-above-level plot provided for the storage of waste to a height of 1.5-2.0 meters above ground level. The area of the landfill occupies 1.02 hectares, of which the used area covers 0.89 ha [Guidelines 2011]. The landfill capacity is estimated at about $35700 \mathrm{~m}^{3}$, and the volume of stored wastes at about $23147 \mathrm{~m}^{3}(7.72 \mathrm{Mg})$. The landfill surrounded with a fence is equipped with vegetation isolation belt. The disinfectant

\footnotetext{
According to data obtained from the commune, more than $63.5 \%$ of the municipality area is agricultural land with domination of arable land, where considerable amounts of artificial and natural fertilizers have been used.
}

paddling pool was at the entrance to the landfill. The landfill area and its neighborhood does not have a very diverse morphology - it is slightly hilly area that is slightly tilted to the north. The area with the landfill is characterized by the presence of highly permeable sandy gravel forms to the depth of 30-35 m; in the deeper layers - moderately permeable soil, clay, sand plates - below $100 \mathrm{~m}$, while the impermeable ground $-140 \mathrm{~m}$. The groundwater surface is at the depth below 30 $\mathrm{m}$. These waters are supplied mainly due to the rainwater infiltration. This groundwater flows in a direction according to the surface water flow; they are utilized due to dug wells in the surrounding farms.

The landfill has a natural seal of its bottom and side slopes made of clay with a thickness of $0.5 \mathrm{~m}$. The facility does not have a drainage system for leachate. The leachate is collected in a ditch insulated with a foil and covered with concrete slabs into the concrete well with a capacity of $6 \mathrm{~m}^{3}$. Three wells in close farms are used as points for groundwater status measurement; they are applied as piezometers [Guidelines 2011; Information 2014].

Piezometer P1 (well No 6) located on an inflow of groundwater, north-western side of the landfill; it has the smallest depth of the first water surface (about $10.3 \mathrm{~m}$ p.p.t). Piezometer P2 (well No 1) localized on the south side of the landfill on the groundwater outflow, but not directly in the flow direction. The depth of the first water surface was the largest around $23.5 \mathrm{~m}$ p.p.t. Piezometer P3 (well No 2) located at the lowest point relative to the landfill in a groundwater flow direction on the south-west side. The depth of the first water surface was not the greatest (about 19.6 m p.p.t) (Figure 1). Longitudinal and transverse terrain decline is in the direction of the third piezometer.

Assessment of the groundwater status in the landfill area was made on the basis of the monitoring results received from the municipal office and own research. At the landfill, groundwater monitoring was conducted in accordance with the guidelines set out in Regulation of the Minister of Environment of 9 December 2002 [Regulation 2002$]^{2}$.

It includes measurement of $\mathrm{pH}$, electrolytic conductivity, total organic carbon content (TOC),

Currently, the Regulation of the Minister of Environment from 30 April 2013 on landfills (Dz.U. 2013 pos. 523), is obligatory. 


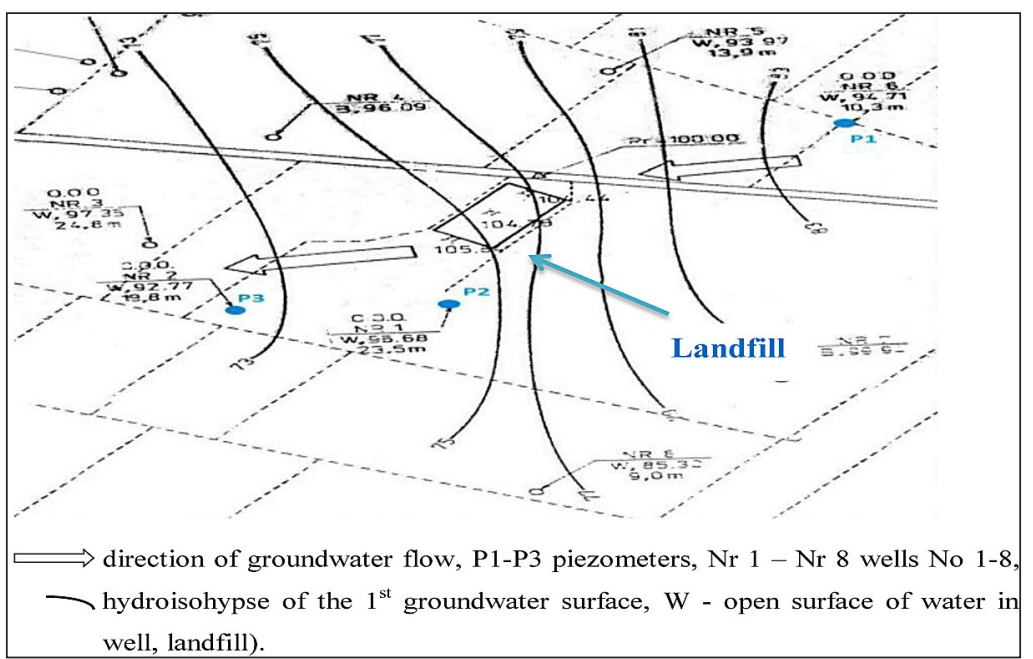

Figure 1. The location of measurement points on the map of the depth of first groundwater surface and the flow direction

sum of poly aromatic hydrocarbons (PAHs), and heavy metals such as zinc $(\mathrm{Zn})$, copper $(\mathrm{Cu})$, lead $(\mathrm{Pb})$, cadmium $(\mathrm{Cd})$, chromium $(\mathrm{Cr})$, and mercury $(\mathrm{Hg})$. All analytical determinations were performed in accordance with the Polish Norm by means of reference methods specified in Annex No. 5 of the decree of Minister of the Environment on the forms and ways of monitoring of surface waters and groundwater from $2009^{3}$. The water acidity was measured by potentiometry, specific electrolytic conductivity (EC) by conductometry. Total organic carbon content was determined using TOC analyzer (IR spectrometry), PAHs applying gas chromatography (GC), heavy metals, i.e. chromium, copper and zinc were quantified by means of flame atomic absorption spectrometry (AAS), lead and cadmium - inductively coupled plasma combined with emission atomic absorption (ICP-EAS), while mercury - AAS according to procedure PN-EN 12338.

Groundwater studies were carried out four times a year, quarterly in 2007-2010 to the beginning of the landfill reclamation works. Reports from monitoring studies include sixteen quarters. The results were compared with the limit values of water quality indicators according to quality classes of groundwater set out in the decree of Minister of Environment from 23 July 2008 on criteria and ways of assessment of groundwater status [Regulation 2008]; also principal statisti-

\footnotetext{
Currently, the Regulation of the Minister of Environment of 15 November 2011 on the forms and manner of monitoring of surface water bodies and groundwater (Dz.U. 2011 No 258 pos. 1550 amended in 2013), is obligatory.
}

cal characteristics: mean, minimum, maximum, median, and standard deviation, were calculated applying Statistica 12 software. In order to compare the quality of water above (P1) with that below the landfill (P2 and P3), statistical analysis of concentrations of selected water quality indicators was performed. The difference significance between mean values of conductivity and PAHs content was calculated using parametric t-Student test for independent variables.

\section{RESULTS AND DISCUSSION}

Based on piezometric measurements of waters around the landfill during the four years (2007-2010), acidity oscillated from 7.2 to 8.21 $\mathrm{pH}$ in the water above the landfill (Table 1) and from 7.21 to $7.93 \mathrm{pH}$ in the water below the landfill (Table 1). These values are characteristic for groundwater of I to III class [Regulation 2008].

Within the period of study, reaction of water from piezometer P1 (inlet) underwent the biggest fluctuations, while the smallest oscillations were found in waters from piezometer P2 (Table 1, Figure 2a).

The acidity depends mainly on the type of deposited waste and the age of the landfill. Depositing of wastes in the analyzed landfill began in 1990 and continued until the beginning of reclamation. With time and due to the decreasing amount of organic matter deposited in the mass of waste, the amount of acidic products decreased as well [Wiater 2011].

The change in $\mathrm{pH}$ value is also affected by produced ammonium ions migrating from the 
Table 1. Basic ststics of water parametres

\begin{tabular}{|l|c|c|c|c|c|c|c|c|c|}
\hline Measurement point & \multicolumn{3}{|c|}{ Piezometer 1(P1) } & \multicolumn{3}{c|}{ Piezometer 2 (P2) } & \multicolumn{3}{c|}{ Piezometer 3 (P3) } \\
\hline Parameters & $\begin{array}{c}\text { Reaction, } \\
\mathrm{pH}\end{array}$ & $\begin{array}{c}\text { Electrolytic } \\
\text { conductivity } \\
{\left[\mu \mathrm{S} \cdot \mathrm{cm}^{-1}\right]}\end{array}$ & $\begin{array}{c}\mathrm{PAHs} \\
{\left[\mu \mathrm{g} \cdot \mathrm{m}^{3}\right]}\end{array}$ & $\begin{array}{c}\text { Reaction, } \\
\mathrm{pH}\end{array}$ & $\begin{array}{c}\text { Electrolytic } \\
\text { conductivity } \\
{\left[\mu \mathrm{s} \cdot \mathrm{cm}^{-1}\right]}\end{array}$ & $\begin{array}{c}\mathrm{PAHs} \\
{\left[\mu \mathrm{g} \cdot \mathrm{m}^{3}\right]}\end{array}$ & $\begin{array}{c}\text { Reaction, } \\
\mathrm{pH}\end{array}$ & $\begin{array}{c}\text { Electrolytic } \\
\text { conductivity } \\
{\left[\mu \mathrm{S} \cdot \mathrm{cm}^{-1}\right]}\end{array}$ & $\begin{array}{c}\text { PAHs } \\
{\left[\mu \mathrm{\mu g} \cdot \mathrm{m}^{3}\right]}\end{array}$ \\
\hline Minimum & 7.20 & 720 & 0.50 & 7.21 & 536 & 0.50 & 7.23 & 539 & 0.50 \\
\hline Maximum & 8.21 & 1108 & 8.76 & 7.75 & 756 & 12.47 & 7.93 & 756 & 16.10 \\
\hline Mean & - & 840 & 2.39 & - & 638 & 3.83 & - & 653 & 3.94 \\
\hline Standard deviation & - & 134.6 & 2.03 & - & 61.7 & 3.70 & - & 69.4 & 4.76 \\
\hline Median & - & 780 & 2.02 & - & 638 & 1.98 & - & 643 & 2.02 \\
\hline
\end{tabular}
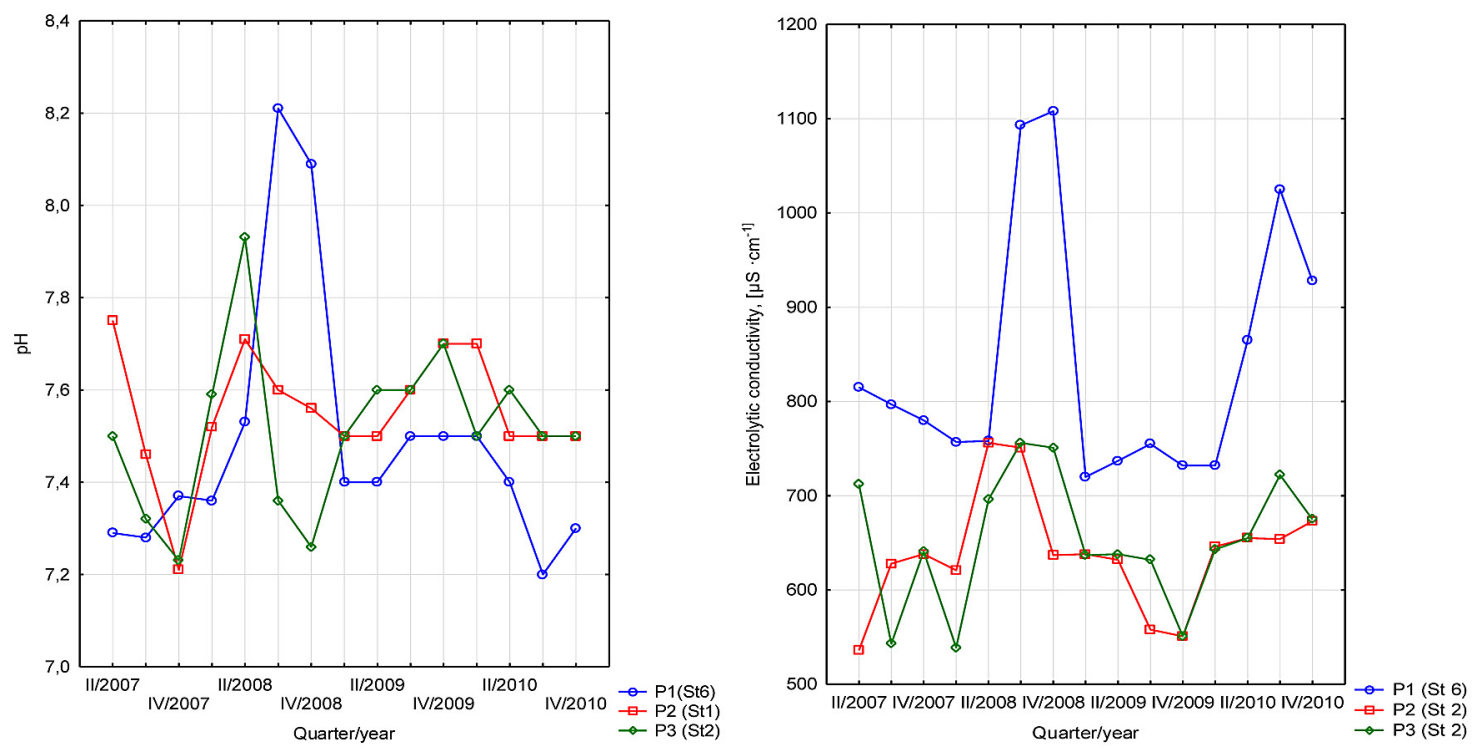

Figure 2. The quarterly change in $\mathrm{pH}$ and conductivity in the piezometric waters

bed, which promotes higher water reaction, even in the first period of decomposition [Jagiełło 2003].

The second analyzed physicochemical indicator of water was the specific electrolytic conductivity (PEW), which during the tests in most cases reached values characteristic for the first purity class in waters from piezometers $\mathrm{P} 2$ and $\mathrm{P} 3$ (below the landfill). Only occasionally, at these points recorded conductivity values were 700 $\mu \mathrm{S} \cdot \mathrm{cm}^{-1}$, while not exceeding $756 \mu \mathrm{S} \cdot \mathrm{cm}^{-1}$ (II and III class) [Regulation 2008]. Waters from piezometer $\mathrm{P} 1$ revealed conductivity from $720 \mu \mathrm{S} \cdot \mathrm{cm}^{-1}$ to $1108 \mu \mathrm{S} \cdot \mathrm{cm}^{-1}$ (Table 1, Figure 2b). These values are within the acceptable limits for II-III class of water purity. The increase in conductivity usually means getting minerals to the water from mineral waste deposited in the landfill, which marks a clear impact of the landfill on the value of this indicator. Definitely higher conductivity values found in waters from piezometer P1 located on the northern side (above the landfill), testify the supply of anthropogenic pollution resulting from the exothermic decomposition processes of organic matter [Wiater 2011]. Statistical processing of EC results showed the existence of small differences between the median and average value in waters from piezometers P2 and P3 (Table 1). The highest dispersion of EC results was obtained for P3 - the highest standard deviation - 134.6 (Table 1).

At the same time, based on the statistical tStudent test used at the significance level of $p<0.05$, it was found that the differences between mean values of conductivity (EC) for water above the landfill (P1) and water below landfill (water from piezometers $\mathrm{P} 2$ and $\mathrm{P} 3$ ) during the study period, were statistically significant.

The summarizing parameters that are commonly used to assess the degree of contamination include the total organic carbon concentration (TOC), which is the sum of carbon contained in organic compounds in the leachate and groundwater. Organic carbon concentration decreased the quality of tested water. Studied water from piezometer P1 was classified for class I of water 
Table 2. Particular indicators of ground water quality P1

\begin{tabular}{|c|c|c|c|c|c|c|c|c|}
\hline \multirow{2}{*}{ Quarter, Year } & \multirow{2}{*}{$\begin{array}{l}\text { TOC } \\
{\left[\mathrm{g} \cdot \mathrm{m}^{3}\right]}\end{array}$} & \multirow{2}{*}{$\begin{array}{c}\text { PAHs } \\
{\left[\mu \mathrm{g} \cdot \mathrm{m}^{3}\right]}\end{array}$} & \multicolumn{6}{|c|}{ Metals $\left[\mathrm{g} \cdot \mathrm{m}^{-3}\right]$} \\
\hline & & & $\mathrm{Cr}$ & $\mathrm{Zn}$ & $\mathrm{Cd}$ & $\mathrm{Cu}$ & $\mathrm{Pb}$ & $\mathrm{Hg}$ \\
\hline I/2007 & $<\mathrm{LOQ}$ & - & $<\mathrm{LOQ}$ & 0.088 & $<\mathrm{LOQ}$ & $<\mathrm{LOQ}$ & $<\mathrm{LOQ}$ & 0.0005 \\
\hline II/2007 & $<\mathrm{LOQ}$ & 2.26 & $<\mathrm{LOQ}$ & 0.125 & $<\mathrm{LOQ}$ & $<\mathrm{LOQ}$ & $<\mathrm{LOQ}$ & $<\mathrm{LOQ}$ \\
\hline III/2007 & $<\mathrm{LOQ}$ & 0.94 & $<\mathrm{LOQ}$ & 0.093 & $<\mathrm{LOQ}$ & $<\mathrm{LOQ}$ & $<\mathrm{LOQ}$ & $<\mathrm{LOQ}$ \\
\hline IV/2007 & $<\mathrm{LOQ}$ & 3.10 & $<\mathrm{LOQ}$ & 0.079 & $<\mathrm{LOQ}$ & $<\mathrm{LOQ}$ & $<\mathrm{LOQ}$ & $<\mathrm{LOQ}$ \\
\hline I/2008 & $<\mathrm{LOQ}$ & 2.00 & $<\mathrm{LOQ}$ & 0.062 & 0.0005 & $<\mathrm{LOQ}$ & $<\mathrm{LOQ}$ & $<\mathrm{LOQ}$ \\
\hline II/2008 & $<\mathrm{LOQ}$ & 2.83 & $<\mathrm{LOQ}$ & 0.050 & $<\mathrm{LOQ}$ & $<\mathrm{LOQ}$ & $<\mathrm{LOQ}$ & $<\mathrm{LOQ}$ \\
\hline III/2008 & $<\mathrm{LOQ}$ & 0.50 & $<\mathrm{LOQ}$ & 0.020 & $<\mathrm{LOQ}$ & $<\mathrm{LOQ}$ & $<\mathrm{LOQ}$ & $<\mathrm{LOQ}$ \\
\hline IV/2008 & $<\mathrm{LOQ}$ & 1.91 & $<\mathrm{LOQ}$ & 0.066 & $<\mathrm{LOQ}$ & $<\mathrm{LOQ}$ & $<\mathrm{LOQ}$ & $<\mathrm{LOQ}$ \\
\hline I/2009 & $<\mathrm{LOQ}$ & 8.76 & 0.002 & 0.028 & $<\mathrm{LOQ}$ & $<\mathrm{LOQ}$ & $<\mathrm{LOQ}$ & $<\mathrm{LOQ}$ \\
\hline II/2009 & $<\mathrm{LOQ}$ & 2.07 & $<\mathrm{LOQ}$ & 0.050 & $<\mathrm{LOQ}$ & $<\mathrm{LOQ}$ & $<\mathrm{LOQ}$ & $<\mathrm{LOQ}$ \\
\hline III/2009 & 2.89 & 2.02 & $<\mathrm{LOQ}$ & 0.075 & $<\mathrm{LOQ}$ & $<\mathrm{LOQ}$ & $<\mathrm{LOQ}$ & $<\mathrm{LOQ}$ \\
\hline IV/2009 & $<\mathrm{LOQ}$ & 4.06 & $<\mathrm{LOQ}$ & 0.072 & $<\mathrm{LOQ}$ & $<\mathrm{LOQ}$ & $<\mathrm{LOQ}$ & $<\mathrm{LOQ}$ \\
\hline I/2010 & $<\mathrm{LOQ}$ & 2.46 & $<\mathrm{LOQ}$ & 0.360 & 0.0010 & 0.008 & 0.009 & $<\mathrm{LOQ}$ \\
\hline II/2010 & 2.20 & 0.50 & 0.002 & 0.078 & $<\mathrm{LOQ}$ & $<\mathrm{LOQ}$ & $<\mathrm{LOQ}$ & $<\mathrm{LOQ}$ \\
\hline III/2010 & 2.26 & 0.50 & $<\mathrm{LOQ}$ & 0.130 & $<\mathrm{LOQ}$ & $<\mathrm{LOQ}$ & $<\mathrm{LOQ}$ & $<\mathrm{LOQ}$ \\
\hline IV/2010 & $<\mathrm{LOQ}$ & 1.96 & $<\mathrm{LOQ}$ & 0.290 & $<\mathrm{LOQ}$ & 0.012 & 0.009 & $<\mathrm{LOQ}$ \\
\hline
\end{tabular}

* LOQ - limit of quantification.

quality, except from organic carbon concentration in the first quarter of 2009, when it was qualified to class II (Table 2). In the case of piezometers $\mathrm{P} 2$ and $\mathrm{P} 3$, water quality was classified into classes I-III (Tables 2, 3).

TOC concentration in tested waters from piezometers $1-3$ is diverse and may indicate the impact of pollutants in the leachate generated in the landfill on the state of groundwater contamination as indicated by clearly increased carbon concentrations in waters from piezometers $\mathrm{P} 2$ and $\mathrm{P} 3$ located at the outlet (Tables 2,3). Lowering the carbon concentration in analyzed waters along with increasing the distance from the landfill is the evidence of the infiltration role of soil in its retention [Tipping, Woof 1991].

The sum of polycyclic aromatic hydrocarbons (PAHs) in tested waters throughout the study period 2007-2010 was lower than the limit value for class I of groundwater, therefore, they are qualified as $1^{\text {st }}$ class. It was found, however, that the sum of PAHs below the landfill in waters from piezometer P2 (average $3.83 \mu \mathrm{g} \cdot \mathrm{m}^{3}$ ) and P3 (average 3.94 $\mu \mathrm{g} \cdot \mathrm{m}^{3}$ ) was higher than the value in P1 (Table 1-3) indicating the influence of the landfill on these substances concentrations in groundwater.

At the same time, on the basis of a statistical $\mathrm{t}$-Student test used at the level of $\mathrm{p}<0.05$, it was found that the differences between mean values of PAHs indicators for water above (P1) and be- low the landfill (water from piezometers P2 and P3), were statistically significant during the study.

The highest scatter of PAHs results was obtained for P3 - the highest standard deviation 4.76 (Table 1). Ashes and slags from home furnaces, which were often deposited, especially on older landfills, are the source of PAHs [Brandli, Bucheli, Kupper, Furrer, Stadelmann, Tarradellas 2005; Rosik-Dulewska, Karwaczyńska, Ciesielczuk 2007].

Mercury concentrations in groundwater from piezometers $1-3$, during the whole study period, were within the standards for class I of groundwater quality, and due to heavy metals, such as chromium, copper, lead, in most cases qualified it to the same class. Only in 2010, there was an increase in the concentrations of these metals in the tested waters (Tables 2 and 3).

Concentration of zinc in waters from piezometers 1-3 was elevated throughout the whole study period (II and III class), as well as the concentration of cadmium (I and IV class). The largest concentrations of heavy metals were found in 2010 in all waters from piezometers 1-3.

Elevated concentrations of cadmium in waters from piezometer 1 (the uppermost) classifying these waters for part of 2010 to the IV class may indicate the use of phosphate fertilizers on farmlands representing approximately $64 \%$ of the commune area. The phosphate fertilizers are an 
Table 3. Indicators of ground water quality P2 and P3

\begin{tabular}{|c|c|c|c|c|c|c|c|c|}
\hline \multirow{2}{*}{ Quarter, Year } & \multirow{2}{*}{$\begin{array}{c}\text { TOC } \\
{\left[\mathrm{g} \cdot \mathrm{m}^{3}\right]}\end{array}$} & \multirow{2}{*}{$\begin{array}{c}\text { PAHs } \\
{\left[\mu \mathrm{g} \cdot \mathrm{m}^{3}\right]}\end{array}$} & \multicolumn{6}{|c|}{ Metals $\left[\mathrm{g} \cdot \mathrm{m}^{-3}\right]$} \\
\hline & & & $\mathrm{Cr}$ & $\mathrm{Zn}$ & $\mathrm{Cd}$ & $\mathrm{Cu}$ & $\mathrm{Pb}$ & $\mathrm{Hg}$ \\
\hline \multicolumn{9}{|c|}{ Piezometer 2} \\
\hline $1 / 2007$ & $<\mathrm{LOQ}$ & - & $<\mathrm{LOQ}$ & 0.020 & $<\mathrm{LOQ}$ & $<\mathrm{LOQ}$ & $<\mathrm{LOQ}$ & 0.0005 \\
\hline II/2007 & $<\mathrm{LOQ}$ & 1.53 & 0.002 & 0.074 & $<\mathrm{LOQ}$ & $<\mathrm{LOQ}$ & $<\mathrm{LOQ}$ & LOQ \\
\hline III/2007 & $<\mathrm{LOQ}$ & 0.87 & 0.002 & 0.128 & $<\mathrm{LOQ}$ & $<\mathrm{LOQ}$ & $<L O Q$ & $<\mathrm{LOQ}$ \\
\hline IV/2007 & $<\mathrm{LOQ}$ & 3.08 & $<L O Q$ & 0.198 & $<\mathrm{LOQ}$ & $<\mathrm{LOQ}$ & $<L O Q$ & $<\mathrm{LOQ}$ \\
\hline 1/2008 & $<\mathrm{LOQ}$ & 1.98 & $<\mathrm{LOQ}$ & 0.062 & 0.0005 & $<\mathrm{LOQ}$ & $<\mathrm{LOQ}$ & $<\mathrm{LOQ}$ \\
\hline $11 / 2008$ & $<\mathrm{LOQ}$ & 1.42 & $<L O Q$ & 0.050 & LOQ & $<\mathrm{LOQ}$ & $<\mathrm{LOQ}$ & $<\mathrm{LOQ}$ \\
\hline III/2008 & $<\mathrm{LOQ}$ & 0.50 & $<\mathrm{LOQ}$ & 0.020 & $<\mathrm{LOQ}$ & $<\mathrm{LOQ}$ & $<\mathrm{LOQ}$ & $<\mathrm{LOQ}$ \\
\hline IV/2008 & $<\mathrm{LOQ}$ & 1.96 & $<L O Q$ & 0.066 & $<\mathrm{LOQ}$ & $<\mathrm{LOQ}$ & $<\mathrm{LOQ}$ & $<\mathrm{LOQ}$ \\
\hline 1/2009 & $<\mathrm{LOQ}$ & 5.85 & 0.002 & 0.028 & $<\mathrm{LOQ}$ & $<\mathrm{LOQ}$ & $<\mathrm{LOQ}$ & $<\mathrm{LOQ}$ \\
\hline $11 / 2009$ & $<\mathrm{LOQ}$ & 7.68 & $<L O Q$ & 0.050 & $<\mathrm{LOQ}$ & $<\mathrm{LOQ}$ & $<\mathrm{LOQ}$ & $<\mathrm{LOQ}$ \\
\hline III/2009 & 7.16 & 3.16 & 0.002 & 0.075 & $<\mathrm{LOQ}$ & $<\mathrm{LOQ}$ & $<\mathrm{LOQ}$ & $<\mathrm{LOQ}$ \\
\hline IV/2009 & $<\mathrm{LOQ}$ & 12.47 & $<L O Q$ & 0.072 & $<\mathrm{LOQ}$ & $<\mathrm{LOQ}$ & $<\mathrm{LOQ}$ & $<\mathrm{LOQ}$ \\
\hline $1 / 2010$ & $<\mathrm{LOQ}$ & 7.24 & $<L O Q$ & 0.360 & 0.0010 & 0.008 & 0.009 & $<\mathrm{LOQ}$ \\
\hline II/2010 & 3.20 & 0.50 & 0.002 & 0.078 & $<\mathrm{LOQ}$ & $<\mathrm{LOQ}$ & $<\mathrm{LOQ}$ & $<\mathrm{LOQ}$ \\
\hline III/2010 & $<\mathrm{LOQ}$ & 0.50 & $<\mathrm{LOQ}$ & 0.130 & 0.0070 & $<\mathrm{LOQ}$ & $<\mathrm{LOQ}$ & $<\mathrm{LOQ}$ \\
\hline IV/2010 & $<\mathrm{LOQ}$ & 0.80 & 0.003 & 0.290 & $<\mathrm{LOQ}$ & 0.012 & 0.009 & $<\mathrm{LOQ}$ \\
\hline \multicolumn{9}{|c|}{ Piezometer 3} \\
\hline I/2007 & $<\mathrm{LOQ}$ & - & $<\mathrm{LOQ}$ & 0.070 & $<\mathrm{LOQ}$ & $<\mathrm{LOQ}$ & $<\mathrm{LOQ}$ & 0.0005 \\
\hline II/2007 & $<\mathrm{LOQ}$ & 1.38 & $<L O Q$ & 0.028 & $<\mathrm{LOQ}$ & $<\mathrm{LOQ}$ & $<\mathrm{LOQ}$ & $<\mathrm{LOQ}$ \\
\hline III/2007 & $<\mathrm{LOQ}$ & 11.74 & $<L O Q$ & 0.111 & $<\mathrm{LOQ}$ & $<\mathrm{LOQ}$ & $<\mathrm{LOQ}$ & $<\mathrm{LOQ}$ \\
\hline IV/2007 & $<\mathrm{LOQ}$ & 3.05 & $<\mathrm{LOQ}$ & 0.214 & $<\mathrm{LOQ}$ & $<\mathrm{LOQ}$ & $<\mathrm{LOQ}$ & $<\mathrm{LOQ}$ \\
\hline 1/2008 & $<\mathrm{LOQ}$ & 2.02 & $<L O Q$ & 0.082 & 0.0005 & 0.004 & $<\mathrm{LOQ}$ & $<\mathrm{LOQ}$ \\
\hline $11 / 2008$ & $<\mathrm{LOQ}$ & 0.88 & $<\mathrm{LOQ}$ & 0.005 & $<\mathrm{LOQ}$ & $<\mathrm{LOQ}$ & $<\mathrm{LOQ}$ & $<\mathrm{LOQ}$ \\
\hline III/2008 & $<\mathrm{LOQ}$ & 0.50 & $<\mathrm{LOQ}$ & 0.170 & $<\mathrm{LOQ}$ & $<\mathrm{LOQ}$ & $<\mathrm{LOQ}$ & $<\mathrm{LOQ}$ \\
\hline IV/2008 & $<\mathrm{LOQ}$ & 1.70 & $<L O Q$ & 0.230 & $<\mathrm{LOQ}$ & $<\mathrm{LOQ}$ & $<\mathrm{LOQ}$ & $<\mathrm{LOQ}$ \\
\hline $1 / 2009$ & $<\mathrm{LOQ}$ & 16.10 & 0.012 & 0.160 & 0.0006 & $<\mathrm{LOQ}$ & $<\mathrm{LOQ}$ & $<\mathrm{LOQ}$ \\
\hline $11 / 2009$ & $<\mathrm{LOQ}$ & 6.36 & $<L O Q$ & 0.093 & $<\mathrm{LOQ}$ & $<\mathrm{LOQ}$ & $<\mathrm{LOQ}$ & $<\mathrm{LOQ}$ \\
\hline III/2009 & 3.58 & 2.12 & 0.002 & 0.200 & $<\mathrm{LOQ}$ & $<\mathrm{LOQ}$ & $<\mathrm{LOQ}$ & $<\mathrm{LOQ}$ \\
\hline IV/2009 & $<\mathrm{LOQ}$ & $<\mathrm{LOQ}$ & $<\mathrm{LOQ}$ & 0.294 & $<\mathrm{LOQ}$ & $<\mathrm{LOQ}$ & $<\mathrm{LOQ}$ & $<\mathrm{LOQ}$ \\
\hline I/2010 & $<L O Q$ & 9.00 & 0.026 & 0.160 & 0.0010 & 0.004 & 0.009 & $<\mathrm{LOQ}$ \\
\hline II/2010 & 5.20 & 0.50 & 0.002 & 0.150 & 0.0005 & 0.004 & $<\mathrm{LOQ}$ & $<\mathrm{LOQ}$ \\
\hline III/2010 & 2.26 & $<\mathrm{LOQ}$ & $<L O Q$ & 0.020 & 0.0070 & $<\mathrm{LOQ}$ & $<\mathrm{LOQ}$ & $<\mathrm{LOQ}$ \\
\hline IV/2010 & $<\mathrm{LOQ}$ & 2.80 & 0.004 & 0.480 & $<\mathrm{LOQ}$ & 0.011 & 0.009 & $<\mathrm{LOQ}$ \\
\hline
\end{tabular}

* LOQ - limit of quantification.

important source of cadmium in soil, from which due to infiltration, cadmium characterized by high mobility, migrates to the waters.

Concentrations of some heavy metals vary depending on the degradation phase of substances deposited in the landfill. During the acidic phase, at low $\mathrm{pH}$, which increases the solubility of metals in water, the highest concentrations of metals occur. With an increase of $\mathrm{pH}$ values, these concentrations are reduced. At the same time, there were no differences in concentrations of such metals as cadmium, chromium, copper, nickel, arsenic, and lead in the leachate between acid and methane phases. Such difference appears only in the case of zinc [Ehrig 1980, Kruse 1994].

This situation was often observed in the case of municipal waste storage without the use of sealing the basin, which is discussed by Szymanski [1995]. At the same time, in case of the studied landfill, the groundwater pollution did not decrease significantly along with increasing the distance from the edge of the landfill. 
The impact on groundwater quality in the vicinity of the analyzed landfill could be exerted by infiltration of leachate which poured out of the storage tank, from which they were not exported during operation and increased agricultural activity on lands adjacent to the facility. Similar conclusions were drawn by Vaverková and Adamcová [2015].

\section{CONCLUSIONS}

1. The quality of groundwater in the study area varies depending on the measurement point (piezometer). Water in the piezometer located at the lowest point of the chamber was characterized by the highest concentrations of tested pollutants.

2. Statistical analysis of water quality from piezometers located above the landfill (P1) and downstream (P2 and P3) showed that statistically significant differences $(\mathrm{p}<0.05)$ between these two points are for the PAHs content and conductivity.

3. The reason for the release of pollutants into groundwater may be leaking landfill base resulting from inaccuracies in its construction or damage during operation.

4. Groundwater quality was modified not only by the action of the landfill, but it could also be the result of increased agricultural activity nearby.

\section{REFERENCES}

1. Brandli R.C., Bucheli T.D., Kupper D., Furrer R., Stadelmann F.X. Tarradellas J. 2005. Persistent organic pollutants in source-separated compost and its feedstock materials - a review for field study. Journal of Environmental Quality 34, 3, 735-760.

2. Butt T.E., Lockley E., Oduyemi K.O.K. 2008. Risk assessment of landfill disposal sites - State of art. Waste Management, vol. 28, 952-964.

3. Ehrig H.J. 1980. Beitrag zum quantitativen und qualitativen Wasserhaushalt vonMülldeponien, Veröffentlichungen des Institutes für Stadtbauwesen der TU Braunschweig, 2. Erw. Auflage, 26.

4. El-Fadel M., Bou-Zeid E., Chahine W., Alayli B. 2002. Temporal variation of leachate quality from pre-sorted and baled municipal solid waste with high organic and moisture content, Waste Management 2002, 22, 3, 269-282.
5. Grygorczuk-Petersons E.H., Wiater J. 2012. The impact of municipal waste landfill on groundwater quality. Inżynieria Ekologiczna 31, 38-46.

6. Information 2014. Information of Podlaski Provincial Inspector of Environmental Protection on the state of the environment in Augustow district in 2013. Suwałki.

7. Jagiełło E. 2003. Contamination of groundwater by Swojczyce municipal wastes landfill. Inżynieria Ekologiczna 9, 138-144.

8. Jermołowicz P. 2013. Principles for designing the sealing layers with the use of geo-membranes in landfill, pond, and reservoirs type facilities. Technical conditions for execution and acceptance, as well as basic static calculations http://www.kup.piib.org.pl/tl_files/izba/dokumenty/szkolenia/zasady-projektowania-warstwuszczelniajacych.pdf]

9. Jurczyk Ł., Koc-Jurczyk J., Różalska P. 2011. AOB quantitative dynamics in the biological purification of landfill leachate under anaerobic conditions. Inżynieria i Ochrona Środowiska 2011, t. 14, nr 4, 309-322

10. Klimek A., Wysokiński L., Zawadzka-Kos M., Osęka M., Chrząszcz J. 2010. Guidelines in the field of PRTR for municipal waste landfills. Warszawa.

11. Koc-Jurczyk J., Różak J. 2011. The composition of leachate from reclaimed municipal wastes landfill. Inżynieria Ekologiczna 27: 72-80.

12. Kruse K. 1994. Langfristiges Emissionsgeschehen von Siedlungsabfalldeponien, In Veröffentlichungen des Instituts für Siedlungswasserwirtschaft TU Braunschweig, 54.

13. Leszczyński J. 2011. Pretreatment of leachate from solid wastes landfill by means of coagulation. Inżynieria Ekologiczna 25, 244-250.

14. Guidelines 2011. Guidelines for technical manner of closing the landfill X. 2011. Białystok.

15. PN-B-10290 Geo-membranes. General requirements for the production of geo-membranes for solid waste landfill.

16. Ecological overview of the solid waste landfill for the city and commune X (Podlasie province). 2002. Suwałki.

17. Rosik-Dulewska C., Karwaczyńska U., Ciesielczuk T. 2007. The migration of PAHs from unsealed landfill into groundwater. Rocznik Ochrona Środowiska, Vol. 9, 335-345.

18. Regulation 2002. Regulation of the Minister of Environment from 9 December 2002 on the scope, time, manners, and conditions for waste landfill monitoring. Dz. U. 2002 Nr 220 poz. 1858 z póź. zm.

19. Regulation 2008. Regulation of the Minister of Environment from 23 July 2008 on criteria and ways 
of assessment of groundwater status. Dz.U. 2008 nr 146, poz. 896.

20. Stępniak S. 2001. Quantitative and qualitative characteristics of leachate from municipal landfill. Ochrona Powietrza i Problemy Odpadów, 35 (2), 63-66.

21. Szyc J. 2003. The leachate from municipal landfills: monografia. Wyd. IOŚ, Warszawa.

22. Szyszkowski P. 1998. The impact of municipal landfill in Swojec on the contamination of groundwater in adjacent area. Zeszyty Naukowe AR we Wrocławiu, 349, 209-231.

23. Tipping E., Woof C. 1991.The distribution on humanic substances between the solid and aqueous phases of acid orgganic solis, a description based on humanic heterogeneticy and charge. J. Soil Sci., $42,437-448$

24. Vaverková M., Adamcová D. 2015. Evaluation of landfill leachate pollution: findings from a monitoring study at municipal waste landfill. J. Ecol. Eng. 16 (2), 19-32.

25. Wiater J. 2011. The impact of municipal waste landfills on the quality of groundwater and soil properties. Inżynieria Ekologiczna 26, 133-146.

26. Wiercik P., Szymańska-Pulikowska A. 2010. The impact of municipal waste landfill in Wojczyce on groundwater quality. Infrastruktura i ekologia terenów wiejskich, PAN, Kraków, 8/2, 151-162. 